\title{
Morphology of submerged terraces in southern Lake Baikal
}

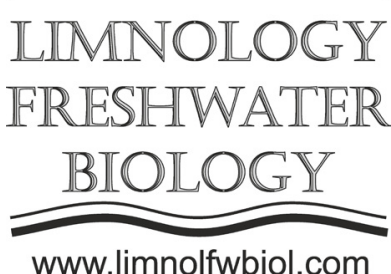

\author{
Osipov E.Y.
}

Limnological Institute, Siberian Branch of the Russian Academy of Sciences, Ulan-Batorskaya Str., 3, Irkutsk, 664033, Russia

\begin{abstract}
In this paper we present new data on the morphology and age of submerged terraces of the upper slope (0-200 m depth) along the southeastern coast of Lake Baikal. A morphological analysis of the upper slope in the Pankovka-Vydrinaya-Pereemaya area was performed using bathymetric and hypsometric data. Morphometric characteristics of the modern wave-cut platform were measured and twelve submerged terraces were identified at depths from 34-43 m (T1) to $188 \mathrm{~m}$ (T12). A good correlation was established between the bathymetric and hypsometric data. AMS ${ }^{14} \mathrm{C}$ age of $45 \mathrm{ky} \mathrm{BP}$ obtained from in-situ remains (tooth) of Mammuthus primigenius Blum. buried in Murino Bank sediments suggest that the last regression of Lake Baikal occurred during the Karga time (marine isotope stage, MIS 3). The T1 paleo level correlates well with the $40 \mathrm{~m}$ submerged terrace of the northern Baikal, which confirms the predominantly climatic nature of the lake level fall. It was assumed that a significant width of the modern wave-cut platform is associated with prolonged stabilization of lake level during the Late Pleistocene and Holocene (MIS2-MIS1).
\end{abstract}

Keywords: Lake Baikal, submerged terraces, bathymetry, lake level change

Numerous geological and geomorphological data suggest of both higher and lower levels of Lake Baikal in the past (Mats et al., 2002). The lake level lowering is usually documented by submerged wavecut/abrasion platforms, sedimentary unconformity and delta systems. Erosional surfaces in the shallow part of Selenga delta record the lake level fluctuations over the past 100 thousand years (Urabe et al., 2004). A series of unconformities in the upperpart of the sedimentary cover in the Malye Ol'khonskieVorota Strait distinguished at a depth of 40-45 m also indicates a regression of the lake during the Last Glaciation (Khlystov et al., 2008). Submerged terraces (wave-cut platforms) were found in the upper slope in the Valukan Cape area (Northern Baikal) at a depth of $40 \mathrm{~m}$ (Osipov and Khlystov, 2010). That is, a decrease in the lake level $40-45 \mathrm{~m}$ below the modern one in Late Pleistocene is confirmed by geological and geomorphological records, however, the spatial and time correlation of this level is still controversial. In this paper we present new data on the morphology and age of submerged terraces on the upper slope along the southeastern coast of Lake Baikal.

In July 2016 the bathymetric surveying was carried out aboard the RV I.D. Papanin along the upper slope in three key regions located near Pankovka, Vydrinaya and Pereemnaya river mouths. Totally, 31 bathymetric profiles were run normal to the shelf break within the depth interval of $0-200 \mathrm{~m}$ to identify submerged terraces. A morphological analysis of upper slope was performed using both bathymetric and hypsometric (digital elevation model, DEM) data.

Analysis of bathymetric data revealed 12 submerged terraces (T1-T12) at depths of 34-43 m (T1), 51-56 m (T2), 65-72 m (T3), 81-86 m (T4), 9296 m (T5), 106-112 m (T6), 119-122 m (T7) , 128129 m (T8), 137-140 m (T9), 160 m (T10), 166-179 $\mathrm{m}$ (T11) and $188 \mathrm{~m}$ (T12). Morphological analysis of bathymetric profiles showed that the shelf break is traced at depths of 15-17 m (an average of $16 \mathrm{~m}$ ). The average slopes of the modern wave-cut platform (shelf) range from $1.6^{\circ}$ (Pereemnaya) to $2.2^{\circ}$ (Vydrinaya), an average of $1.8^{\circ}$. The average width of the platform varies from $350 \mathrm{~m}$ (Vydrinaya) to $760 \mathrm{~m}$ (Pankovka), which indicates a relatively prolongated lake level stabilization close to the modern conditions during both Holocene and Late Pleistocene, for example, during the Last Glacial Maximum (Osipov and Khlystov, 2010). The width of the submerged terraces ranges from 20 to $260 \mathrm{~m}$ (an average of $92 \mathrm{~m}$ ), and the slope from 0.9 to $11.2^{\circ}$ (an average of $4.4^{\circ}$ ). The widest terraces $(>150$ $\mathrm{m}$ ) were observed at Pankovka and Vydrinaya areas (at depths $>80 \mathrm{~m}$ ). At depths of 34-75 $\mathrm{m}$ (Vydrinnaya) and 41-177 $\mathrm{m}$ (Pereemnaya), submarine ridges were discovered, which were interpreted as terraced moraine complexes correlated with the glacial maxima of MIS 4 and MIS 6.

*Corresponding author.

E-mail address: eduard@lin.irk.ru (E.Y. Osipov)

(C) Author(s) 2020. This work is distributed under the Creative Commons Attribution 4.0 License. 


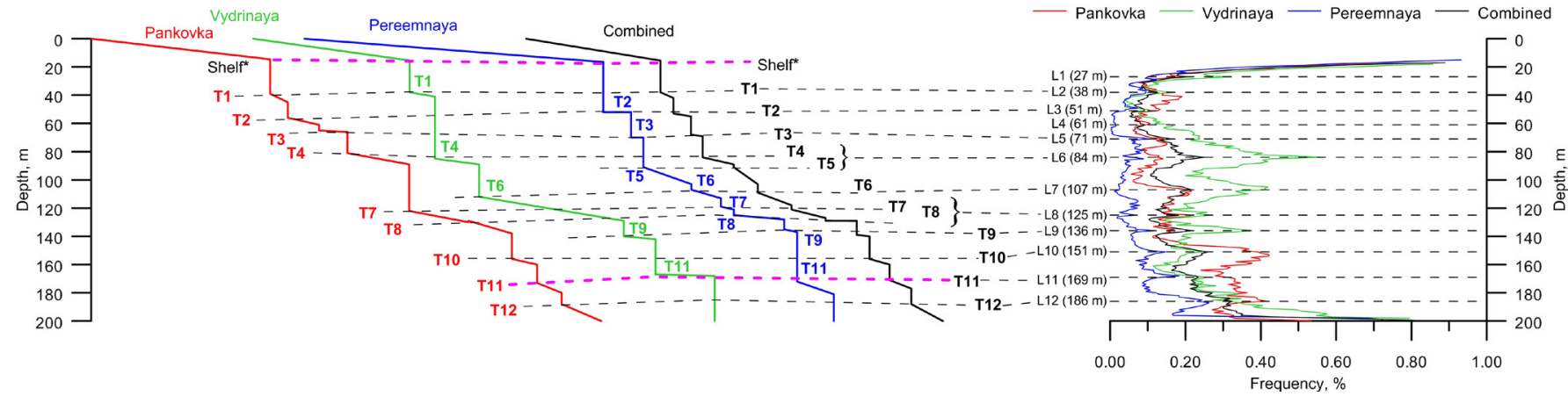

Fig. Correlation between submerged terraces (left panel) and hypsometric curves (right panel) of the upper slope in the Pankovka-Pereemnaya area. Terraces (from T1 to T12) were determined by the depth of notch/inner edge. The peaks of the hypsometric curves (from L1 to L12) indicate the positions of the paleo lake levels.

An analysis of the hypsometric curves derived from the DEMs with $10 \mathrm{~m}$ spatial resolution for the same depth intervals $(0-200 \mathrm{~m})$ also revealed the presence of 12 submerged paleo levels at depths of $27 \pm 1.0 \mathrm{~m}$ (L1), $38 \pm 1.6 \mathrm{~m}$ (L2), $51 \pm 1.9 \mathrm{~m}(\mathrm{~L} 3), 61 \pm 1.9 \mathrm{~m}$ (L4), $71 \pm 1.0 \mathrm{~m}$ (L5), $84 \pm 1.6 \mathrm{~m}$ (L6), $107 \pm 1.3 \mathrm{~m}$ (L7), $125 \pm 1.3 \mathrm{~m}$ (L8), $136 \pm 2.2 \mathrm{~m}$ (L9), $151 \pm 2.2 \mathrm{~m}$ (L10), $169 \pm 1.6 \mathrm{~m}$ (L11) and $186 \pm 2.4 \mathrm{~m}$ (L12). Hypsographic curves of three regions strongly correlate (correlation coefficients 0.78-0.95). The levels L2 and L6-L10 are the most expressed in relief. Identified levels are observed in all three regions, with the exception of L7, which is almost not expressed in Pereemnaya. Paleolevels are most pronounced in Vydrinaya (all except L10) and Pankovka (especially L2, L8, L10-L12), while the least in Pereemnaya. The smallest discrepancies in the level depths between three regions are observed for L6, L8 and L9, and the largest for L12. Good constancy of the depths of the levels in the study area (length along the coast about $60 \mathrm{~km}$ ) suggests their uniform age. Both bathymetric and hypsometric data showed a good correlation between the submerged terraces and paleo lake levels (Fig.).

The L2/T1 level correlates well with the $40 \mathrm{~m}$ submerged terrace of the Northern Baikal (Osipov and Khlystov, 2010), which confirms the hypothesis about the predominantly climatic nature of the lake level fall. The age of this level is defined by remains (tooth) of Mammuthus primigenius Blum. found in situ on Murino Bank slope (Pankovka area) at depth of about $30 \mathrm{~m}$. The organic material from the tooth (collagen) was AMS ${ }^{14} \mathrm{C}$ dated by $\sim 45 \mathrm{ky} \mathrm{BP}$, which allows to correlate the last Lake Baikal regression (L1-L2 / T1) with the Karga time ( 30-50 ky BP, MIS 3).

Significant width of the modern wave-cut platform (shelf) suggests that the lake level during Late Pleistocene and Holocene (MIS2-MIS1) was close to modern one with the Angara River runoff. New data from southern Lake Baikal confirmed the earlier findings of submerged terraces on upper slope in other areas (Khlystov et al., 2008; Osipov and Khlystov, 2010), indicating significant lake level fluctuations during the Late Pleistocene and Holocene due to climate changes. However, in addition to the known 40-meter submerged terrace, additional 11 submerged levels were found at the depth interval of $0-200 \mathrm{~m}$.
The presence of submerged terraces suggests that the change in the level of Lake Baikal was intermittent, with repeated stages of stabilization. The identified submerged paleo levels require additional geophysical and geological studying.

\section{Conclusions}

New data on the morphology and age of submerged terraces of the upper slope (0-200 m depth) along the southeastern coast of Lake Baikal (PankovkaVydrinaya-Pereemaya area) were obtained. Using morphometric analysis of bathymetric data twelve submerged terraces (paleo levels) were identified at depths from 34-43 m (T1) to $188 \mathrm{~m}$ (T12). Radiocarbon AMS dating of in-situ remains of Mammuthus primigenius Blum. buried in Murino Bank sediments confirmed that the last $40 \mathrm{~m}$ regression of Lake Baikal (T1 level) was due to climate change and occurred during the Karga time (marine isotope stage, MIS 3). Morphology of the upper slope suggests the prolonged stabilization of lake level during the Late Pleistocene and Holocene (MIS2MIS1).

\section{Acknowledgements}

The study was supported by the project No. 0345-2019-0006.

\section{References}

Khlystov O.M., Khanaev I.V., Grachev M.A. 2008. Evidence of lowstand of Lake Baikal during the Last Glaciation. Doklady Earth Sciences 422: 1133-1136. DOI: 10.1134/S1028334X08070301

Mats V.D., Fujii S., Mashiko K. et al. 2002. Paleohydrology of Lake Baikal in relation to neotectonics. Russian Geology and Geophysics 43: 142-154.

Osipov E.Y., Khlystov O.M. 2010. Glaciers and meltwater flux to Lake Baikal during the Last Glacial Maximum. Palaeogeography, Palaeoclimatology, Palaeoecology 294: 4-15. DOI: 10.1016/j.palaeo.2010.01.031

Urabe A., Tateishi M., Inouchi Y. et al. 2004. Lakelevel changes during the past 100,000 years at Lake Baikal, southern Siberia. Quaternary Research 62: 214-222. DOI: 10.1016/j.yqres.2004.06.002 